« Khotan, an early center of Buddhism in Chinese Turkestan ", in :J. R. McRea and J. Nattier, eds., Collection of essays 1993: Buddhism across boundaries: Chinese Buddhism and the Western Regions. Sanchung, Fo Guang Shan Foundation for Buddhist and Culture Education, 1999, pp. 265-344.

\title{
Mauro Maggi
}

\section{(2) OpenEdition Journals}

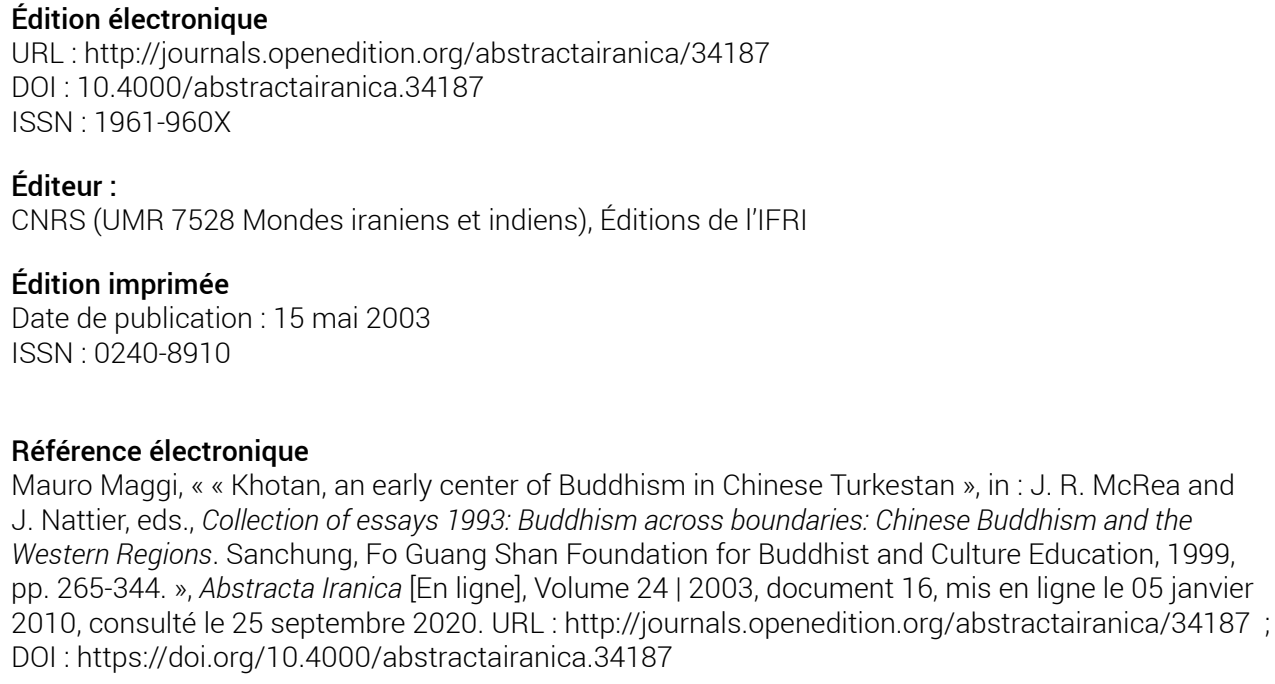

\section{Référence électronique}

Mauro Maggi, « « Khotan, an early center of Buddhism in Chinese Turkestan », in : J. R. McRea and J. Nattier, eds., Collection of essays 1993: Buddhism across boundaries: Chinese Buddhism and the Western Regions. Sanchung, Fo Guang Shan Foundation for Buddhist and Culture Education, 1999, pp. 265-344. ", Abstracta Iranica [En ligne], Volume 24 | 2003, document 16, mis en ligne le 05 janvier 2010, consulté le 25 septembre 2020. URL : http://journals.openedition.org/abstractairanica/34187 ; DOI : https://doi.org/10.4000/abstractairanica.34187 
« Khotan, an early center of Buddhism in Chinese Turkestan ", in : J. R. McRea and J. Nattier, eds., Collection of essays 1993: Buddhism across boundaries: Chinese Buddhism and the Western Regions. Sanchung, Fo Guang Shan Foundation for Buddhist and Culture Education, 1999, pp. 265-344.

Mauro Maggi 
1 An outline of Khotanese (and Tumshuqese) literature containing several novelties. It deals chiefly with four aspects: «the choice of texts for translation..., the local compositions, ... the translation techniques..., how the Khotanese translations compare with the originals as well as with translations into Tibetan and Chinese » (pp. 292-293). Skjærvø posits an interesting classification of Khotanese texts in three periods on the basis of the language used in them: Old, Middle or Late Khotanese. However, the category of Middle Khotanese still escapes a clear definition. The section on translation techniques is the most ample and systematic treatment of the subject to date (pp.312-329). Considering that Buddhologists have so far paid comparatively little attention to Khotanese texts, the information Skjærvø provides concerning the history of the tradition of some Khotanese texts and their relationships with the Tibetan and, particularly, Chinese versions is quite useful and promising (pp. 329-338).

INDEX

Thèmes : 2.1. Langues anciennes

\section{AUTEURS}

MAURO MAGGI

Istituto Universitario Orientale - Naples 